\title{
高強度乱流予混合火炎の微細構造に関する一考察
}

\section{A Study of Microstructures of High Intensity Turbulent Premixed Flames}

\author{
㴊端 学**井田民男* \\ Manabu FUCHIHATA and Tamio IDA
}

(Received November 8, 2004)

\begin{abstract}
We discussed the flame structure of premixed flames in high intensity turbulent fields, where Damköhler numbers were around or lower than unity. In the former study, low Damköhler number flames were successfully formed in relatively weak turbulent reactant flows by using very lean premixture of sufficiently long chemical characteristic time, where the transition of flame structure from 'Distributed reaction zone' to 'Wrinkled laminar flame' was observed. We, in the present study, discussed microstructures of turbulent premixed flames in high intensity turbulent fields of low Damköhler number. As a result, we have suggested two types of microstructures of intense turbulent premixed flames. One is a propagating flame with local extinct protrusions resulting in cylindrical or warped flamelets surrounded by a pseudo-distributed reaction zone, and the other is a propagating flame with local extinction spots resulting in a pseudo-distributed reaction zone. The proposed models are consistent with experimental observations, and the classifications of the two types of flame structures are understood to correspond the boundary separating 'Distributed reaction zone' and 'Well-stirred reactor' on Borghi's diagram.
\end{abstract}

Key Words: Turbulent Premixed Flame, Flame Structure, Distributed Reaction, Well-Stirred Reactor, Flamelet

\section{1. 緒 言}

Summerfield ${ }^{1,2)}$ らが分散反応領域構造を提案して以来 , 高 強度乱流場に形成される火炎の構造について,多くの研究者 が実験的観察および火炎構造モデルの提案を行ってきた。

Chomiak ${ }^{31}$ は燃焼反応が , テイラースケールで伸長を受け たコルモゴロフスケールの渦管内の,スカラー消散率の高い 領域で集中して起こると考えた。これは Tennekes ${ }^{4}$ が示した 乱流の微細構造モデルに基づいた火炎構造モデルであった。 Tabaczynski ${ }^{5}$ はこれと類似の火炎構造モデルをエンジン内の 燃焼に適用し，主に燃焼速度について実験值と一致するとし ている。しかし小林ら ${ }^{6)}$ は Chomiak のモデルと共通する特徵 を持つ伸長円筒状予混合火炎について詳細な検討を行い, 分 散反応領域に分類されるような強い乱流場では火炎伸長率の 制限により円筒状火炎片か存在できないことを明らかにした。 このことから最近では Chomiak のモデルは現実性が低いと 考えられている。

吉田ら ${ }^{7)-10)}$ (対向噴流バーナを用いて分散反応領域に分 類される条件の火炎を形成し,詳細な計測から，燃焼反応は 主に群島状の層流火炎片で起こっており，燃焼反応の後半部 分において微小渦全体が反応する分散反応領域が形成される
としている。しかし群島状の層流火炎片が渦の中心に向かっ て伝ぱし，渦の崩壞に伴って微小渦のスケールに達すれば， あとは瞬間的に燃え尽きるはずである。さらに層流火炎の存 在は火炎面前方の未燃混合気と火炎面背後の既燃ガスとの混 合を抑制するのであり ${ }^{11)}{ }^{12)}$ 燃焼反応後半とはいえ微小渦内 部が，反応速度が低下するほどに未燃混合気と既燃ガスが混 合した状態となるとは考えにくい。

それでは Summerfield 以前の, Damköhler ${ }^{13)} や$ Ballal $^{14)}$ の モデルが正しいのかと言えば,これについても多くの研究に より ${ }^{15)-18)}$,分散反応領域火炎が形成されると判定される乱流 場においても,反応帯の厚みは層流火炎の兰れとほとんど変 わりがなく ,むしろ伸長により薄くなっている場合もあるこ とか報告されている。この反応带構造は近年 thin reaction zone と表現され，高強度乱流予混合火炎構造として提案されてい る。これらの観察結果より，微細渦が火炎帯内の物質輸送を 支配し，火炎帯厚みを増加させるとしたモデルも否定的に考 えざるを得ない。

以上のことから現在では，層流火炎片モデルや thin reaction zone モデルが主流となっており，乱流予混合火炎は局所に おける伸長率 ${ }^{19)}$ や選択拡散効果 ${ }^{20)}$ によって燃焼速度が変化 した層流火炎片により構成されていることか実験的にも検証

* 近畿大学理工学部機械工学科( ( $577-8502$ 大阪府東大阪市小若江 3-4-1)

Department of Mechanical Engineering, School of Science \& Engineering, Kinki University (3-4-1 Kowakae, Higashi-Osaka, Osaka 577-8502 , Japan) 


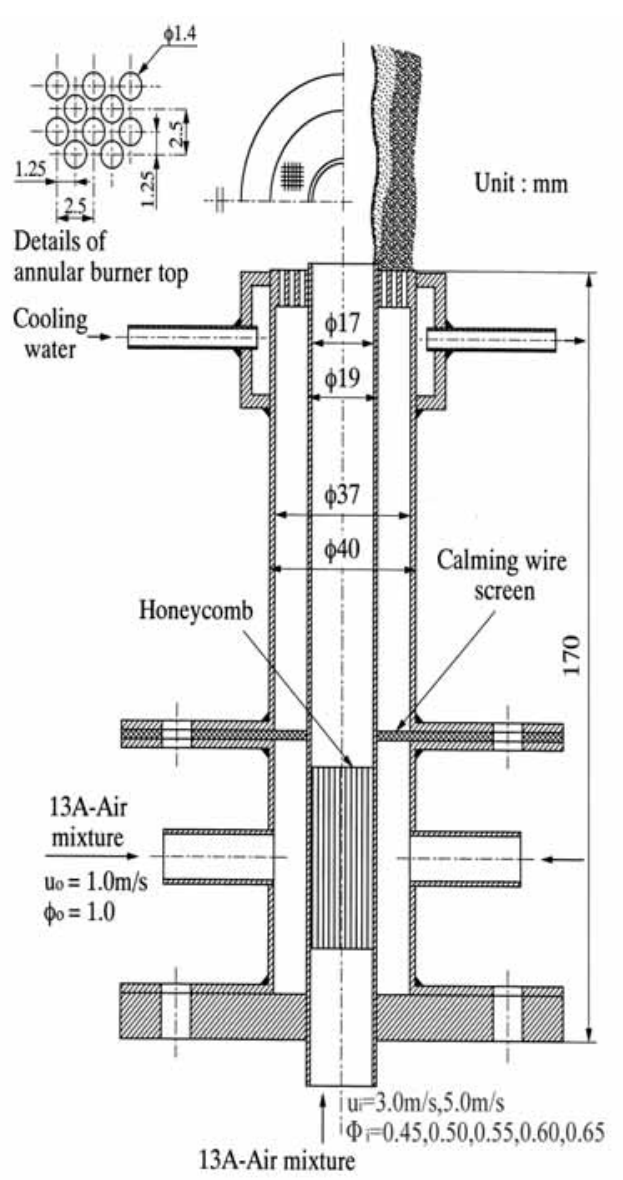

Fig. 1 Burner.

されてきている。

しかしさらに乱流強度があがるとどうなるであろうか。直 接火炎構造に言及してはいないものの，興味深い報告として Klimov と Williams ${ }^{21} の$, 強乱流場では火炎の局所伸長によ り局所的な消炎が起こるとする説や，高橋ら ${ }^{22,23)}$ の，吹き 消え寸前の伝は性を消失した火炎が分散反応領域であるとす る報告などがある。両説はともに，伝ぱ火炎の消炎限界付近 を層流火炎片構造が存在できなくなる条件とみている点で共 通しているとも言える。

これらのモデルに関連しては, 近年急速に発達した LIF 計測により,高強度乱流火炎内に局所消炎領域力確認されて (る24, 25)ことから現実性があるように思われる。しかし， 局所消炎現象と分散反応領域構造との関連があきらかではな いことや, Summerfield らが示した高速乱流中に定在する分 散反応領域火炎が,伝は性を消失した火炎であるとは考えに くいなどの疑問点がある。

高強度乱流場における予混合火炎の構造について，筆者ら は非常に希薄な予混合気流を用いて, 比較的大スケール・弱 乱流強度の流れ場に高強度乱流場と同樣のダムケラ数の小さ い乱流予混合火炎を形成し，さらに計測法に独自の改良を施

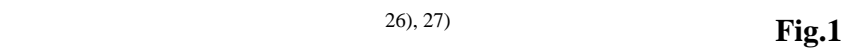
に示す。光の結果，火炎基部せん断層内の公ムケラ数が小さ い領域では伝ぱ火炎はすぐには形成されず,まず予混合気と

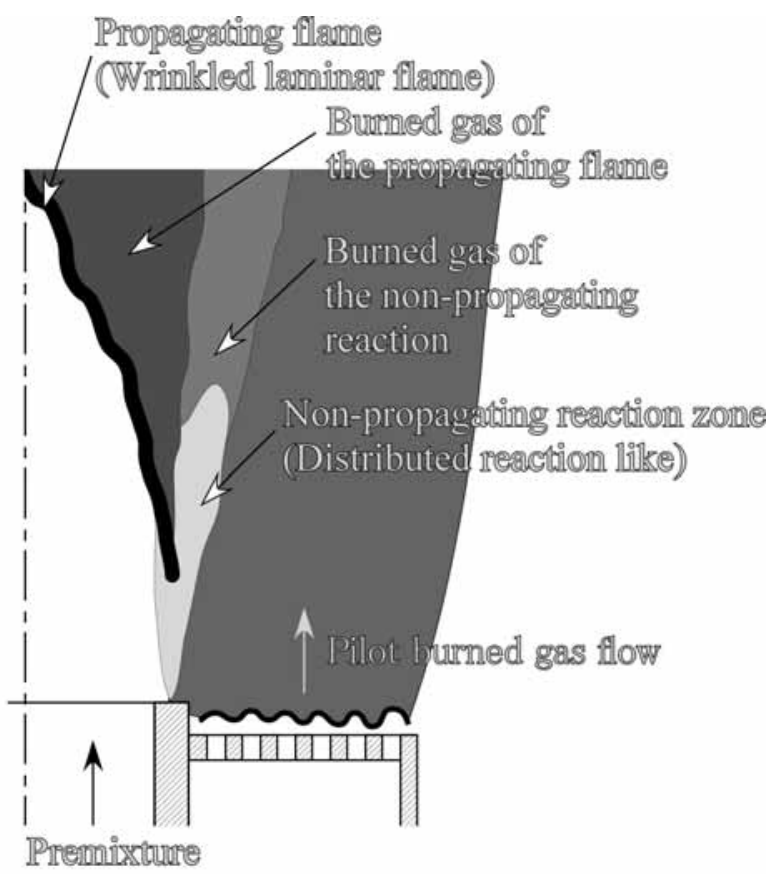

Fig. 2 Flame structure of lean premixture surrounded by high temperature burned gas flow.

既燃ガスとの混合層内で分散反応的な燃焼反応が起きた後， その影響で乱流渦がある程度消散してから伝ぱ火炎が出現す るという, 火炎構造が遷移しつつ燃焼が進行する過程が観察 された (Fig.2 参照)。

本報では，高温既燃ガスに囲まれた予混合気流の燃焼パタ ーンとして ,この火炎構造遷移が一般的に起こるとの考えを もとに，乱流強度が火炎帯内に局所消炎を引き起こす程度に まで至った高強度乱流予混合火炎の微細構造について考察し， 弚の火炎構造モデルを検討する。

\section{2. 高強度乱流予混合火炎の微細構造}

乱流予混合火炎の局所では,未燃予混合気が反応帯をはさ んで高温既燃ガスと隣接しており，光れらの間で分子拡散や 乱流拡散によって熱および物質が移動しつつ, 反応が進行し ている。このような構造は巨視的に乱流予混合火炎を観察し た場合にも当てはまることから，乱流予混合火炎面の形状や 構造がフラクタル性を持つことを指摘した報告 ${ }^{288-311}$ がいく つかなされている。これらのことから考えて，乱流予混合火 炎構造は自己相似性を持っていると考えられる。乥こで,筆 者らにより観察された前述の巨視的な燃烤現象か微細スケー ルでも相似的に起こり得ると考えると，伝ぱ火炎において局 所消炎が起こった場合に，火炎面背後に通り抜けた予混合気 塊に同樣の現象が起こると考えられる。この概念図を Fig.3 に示す。

まずFig.3(a)に示したのは，局所消炎を起こした直後の樣 子である。局所消炎は主に伸長によって引き起こされる ${ }^{32), 33)}$ と考えられるため, 局所消炎部分の予混合気と既燃ガスとの 
Premixture Burned gas Re-ignited laminar flame Burned gas of re-ignited laminar flame

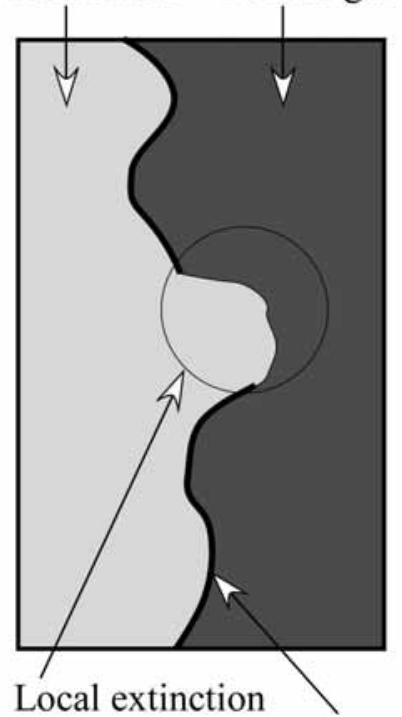
region

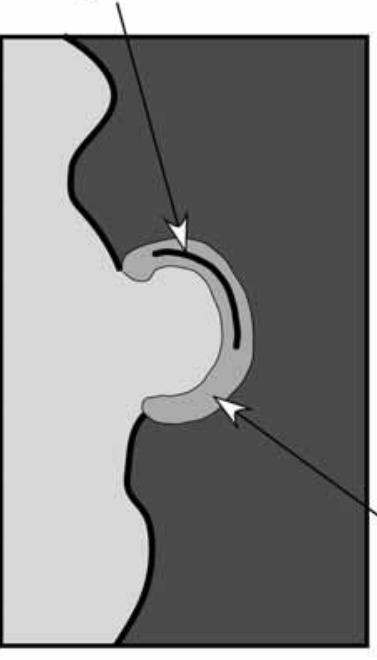

Non-propagating reaction zone

(Distributed reaction like)

(c)

(b)

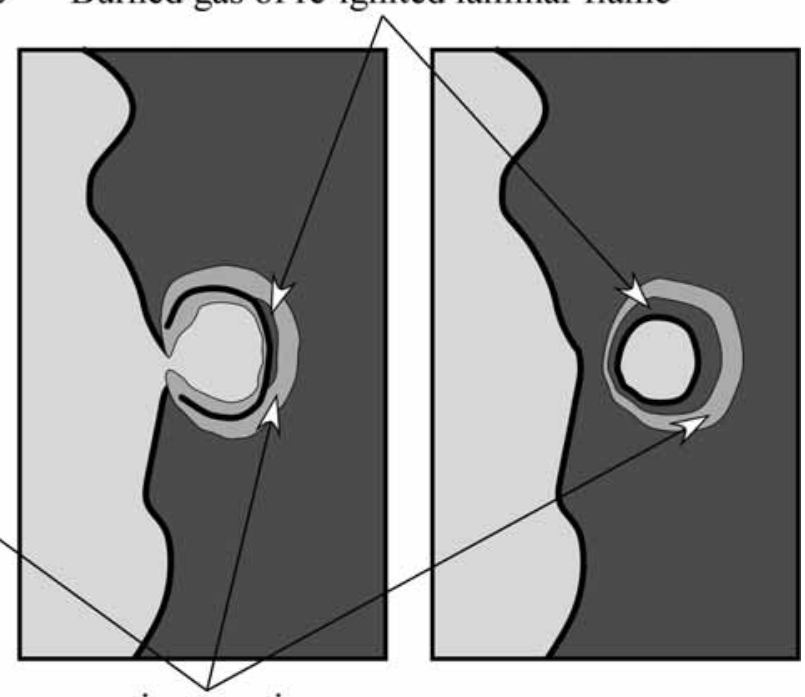

(d)

(a)

Fig. 3 Microstructure of high intensity turbulent premixed flame No. 1.

界面では,火炎面に平行な速度成分の火炎面伝ぱ方向速度勾 配は必然的にきつくなる。さらに局所消炎は, 伝ぱ火炎面前 方に予熱帯が形成できなくなることによって引き起こされる ため，これもまた必然的に，伝ば火炎が存在する場合に比べ て予熱帯か溥く低温なっていると考えられる。このため予熱 帯内における, 小スケール渦の消散量も少なくなるので, 伝 ぱ火炎帯内において予熱帯から反応帯に進入できる渦のスケ 一ルより,さらに小さなスケールの渦までが予混合気と既燃 ガスの界面に到達可能になると考えられる。

局所消炎を起こした予混合気の渦と既燃ガスの界面では， 伝ぱ火炎の再形成に要する時間より乱流混合特性時間の方が 短い場合，すなわちダムケラ数が小さい場合 (この条件は局 所消炎が起こるような領域ではほぼ満たされる)，伝ぱ火炎 の再形成までに予混合気と既燃ガスの混合層が形成される。 产の後, 伝ぱ火炎面が混合層の中央付近に出現する (Fig.3(b) 参照)。やがて渦界面の混合層全体に伝ぱ火炎が形成され， 渦の中心に向かって伝ぱをはじめる。このとき混合層内の， 伝ぱ火炎が出現する位置より既燃ガス側の領域では,伝ぱ火 炎によらない分散反応的な燃焼反応により予混合気か燃焼す る(Fig.3(c)参照)。光して再着火した伝ぱ火炎の既燃ガスが， 分散反応的な反応帯を外側へ押し広げるとともに, 渦内部に 向かって火炎が伝ぱし混合気を燃焼させる。(Fig.3(d)参照)。

Fig.3に示したのは, 一つの渦の断面についての概念図で あり，実際の反応帯は局所消炎を起こして虫食い状になった 伝ぱ火炎の背後に, 分散反応的な反応帯のエンベロープをま とった紐状の円筒層流火炎片，もしくは湾曲した層流火炎片 が折り重なって存在するような構造になると考えられる。再 形成された層流火炎片は,兴の外縁に既燃ガス層を形成しつ
つ未燃混合気側へ伝ぱするので,互いに干渉あるいは混合す ることは起こりにくい。

上記のモデルは，局所で伸長消炎を引き起こす渦のスケー ルが比較的大きな場合に該当し,渦のスケールが小さい場合 は少し違った構造が現れると考えられる。光の概念図をFig.4 に示す。

Fig.4(a)に示したのは, 局所消炎を起こした直後の樣子で あり，スケールが小さいこと以外は Fig.3(a)と条件的な差は ない。Fig.3(b)に示したと同樣に，渦の界面で予混合気と既 燃ガスとの混合層が形成される。ここで闾のスケールが大き い場合には，この混合層中に伝ぱ火炎が再形成されると考え られるが , 渦のスケールがある大きさより小さい場合には， 伝ぱ火炎の再形成までに渦内の予混合気全体か溉燃ガスによ って希釈されてしまい, 伝ぱ火炎が再形成できなくなると考 えられる (Fig.4(b)(c)参照)。光して全体が予混合気と既燃力゙ スの混合層となった渦は, 分散反応的な反応帯として燃焼す る (Fig.4(d)参照)。

Fig.4に示したのは , Fig.3 と同樣に一つの渦の断面につい ての概念図であり，実際の反応帯は局所消炎を起こして虫食 い状になった伝ぱ火炎の背後に，細かな紐状の分散反応的な 反応帯が折り重なって存在する，もしくは紐状の分散反応的 な反応帯が互いに混合することにより，層状になって伝ぱ火 炎の背後に存在するような構造になると考えられる。この場 合は , 渦内部に Fig.3に示したような伝ぱ火炎が再形成され ないため既燃ガス帯が形成されず，紐状の分散反応的な反応 帯が互いに混合すると考えられる。

低ダムケラ数の場に形成される予混合火炎の構造が上記の ようであると仮定したとき,冒頭に挙げた従来の研究報告に 
Premixture Burned gas

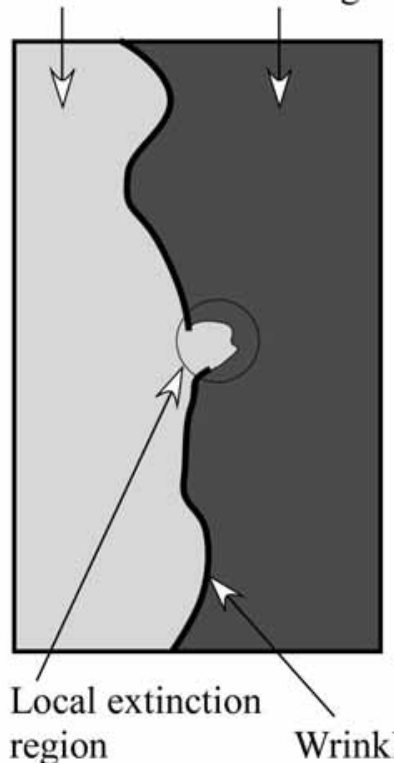

(a)
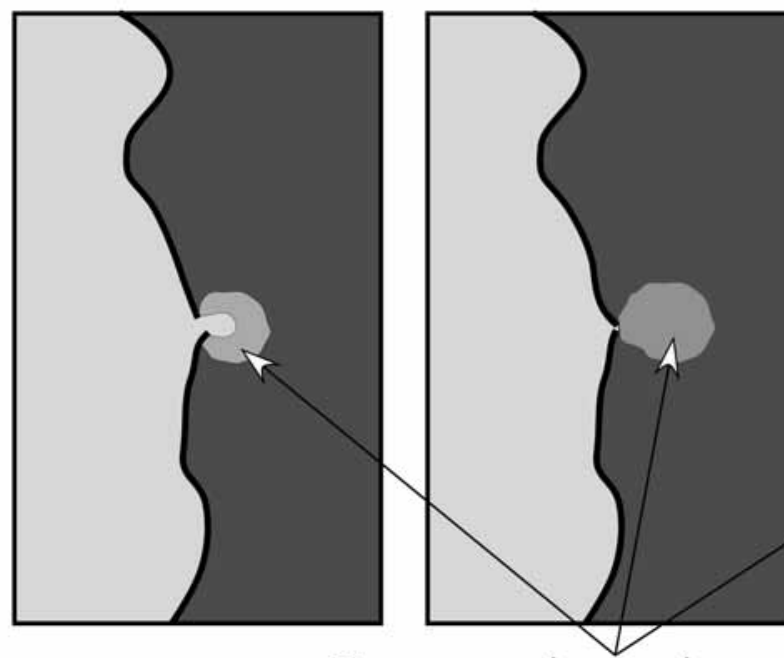

Non-propagating reaction zone (Distributed reaction like)

(c)

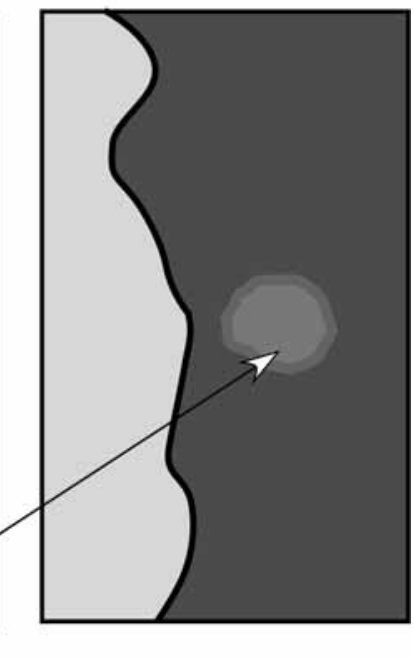

(d)

Fig. 4 Microstructure of high intensity turbulent premixed flame No. 2

ある燃焼現象がどのように説明できるかを以下に考察する。

\section{3 . 従来の研究結果に対する考察}

\section{1 高橋らの研究について}

高橋らの研究 ${ }^{22),}{ }^{23)}$ では可燃限界以下の希薄混合気と高温 燃焼ガスの混合層を利用して,各ムケラ数の小さい火炎を作 り出し, 光の火炎における, 温度, イオン電流およびラジカ ル自発光波形の各種統計解析, 周波数解析の結果が, 強乱流 中に形成された分散反応領域火炎と相似であることから，分 散反応領域火炎は伝は性を消失した火炎であると推定した。

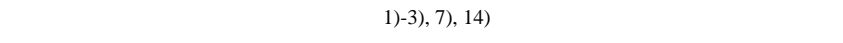
火炎は，可燃性の予混合気流中に定在する火炎であり，決し て伝ば性を消失した火炎ではない。この点について高橋らの 研究では明確な回答が示されていないため,たとえ極めて相 似性か強い各種物理量の計測結果が得られたとしても，従来 観察されてきた分散反応領域火炎と同じ燃烧現象であるとい う確証に欠けていた。しかし, 両者が異なる燃焼形態である と断言するにはあまりにも計測結果の相似性か強かったこと も確かである。光のためこの点については肯定も否定もされ ないまま今日に至っている。

乥こで本研究結果をふまえた場合，高橋らの観察した分散 反応領域火炎が,光の他の研究者らによって観察されてきた 高強度乱流場における予混合気の燃焼現象とどのように対応 するかについて考える。

希薄可燃限界以下の予混合気が燃焼する場合, 基本的に伝 ぱ火炎は出現しない。しかし高温パイロット流が近傍に存在 する場合，予混合気中の燃料と酸素は高温パイロット流から 熱やラジカルの供給を受けて活性化され,分子同志が衝突し
たときに反応を起こす。この反応機構は 2 章で述べた , 分散 反応的な反応帯のものと同一であるといえる。つまり 2 章の 結果に見られるように,可燃範囲内の予混合気か燃焼する場 合でも，伝ぱ火炎が局所消炎を起こすような条件では，乥の 背後に高橋らか観察したものと同じ構造の反応帯が出現し得 るといえる。

2 章に示した火炎構造モデルに従えば，先行する伝ぱ火炎 の局所消炎部分の面積が大きくなるにつれて，火炎面背後の 温度が低下していき, 分散反応的な反応の強度か指数的に低 下していく。すると虫食い状の伝ぱ火炎面背後の温度やラジ カルの量も同樣に減少していくと考えられる。よって, 先行 する伝ぱ火炎面の局所消炎部分の面積がある值以上になると， 火炎は急速に消炎にいたることになる。しかしバーナにパイ ロットバーナが備えられている場合は，火炎面背後へ熱やラ ジカルがより多く供給されることになり，より消炎しにくく なる。高橋らか観察したのはこの究極の燃焼形態であり，パ ッチ状の伝ぱ火炎の既燃ガスを必要とせず,パイロット流の 既燃ガスのみによって反応を維持していたものと考えられる。

\section{2 層流火炎片モデルおよび thin reaction zone モデルにつ いて}

Damköhler ${ }^{13}$ 以来，分散反応領域火炎は層流火炎構造の反 応帯内に反応帯厚み以下のスケールの渦が進入し, 反応帯厚 みが増加されることにより出現するとされてきた。しかし最 近, 計測技術の進歩によって高強度乱流場における火炎帯の 微細構造についての計測が可能となり，乥の結果のほとんど が反応帯厚みは高強度乱流場においても層流火炎の光れとほ とんど差はなく，Kolmogorov スケールが層流火炎帯厚みよ 
り小さい場でも反応帯内では乱流輸送が支配的にはならない ことを示している ${ }^{15-18)}$ 。これは従来の分散反応領域火炎モデ ルでは高強度乱流火炎の構造をうまく説明できないことを意 味している。しかし 2 章に示した火炎構造モデルによれば， 伝ぱ火炎面に局所消炎が起こることが分散反応的な構造の出 現条件であり，小スケールの渦が反応帯内に侵入できなくと も分散反応領域火炎の出現力説明できるため，層流火炎片モ デル , thin reaction zone モデルとも矛盾しないモデルといえ る。

\section{3 光の他の研究に見られる分散反応領域火炎について}

これまで多くの研究者らによって考えられてきた分散反応 領域構造のほとんど3), 5), 7)は Fig.3に示した構造に近いと考 えられる。しかしこの構造では燃焼反応は主に伝ぱ火炎構造 で起こっており,Summerfieldらか観察した distributed reaction zone ${ }^{1), 2)}$ とは少し趣が違うように感じられる。というのは Summerfield らの観察した distributed reaction zone は, 反応の 樣々な段階の領域が層流火炎帯厚みの10 100倍ほどの厚み の領域に分散して存在するとしていたのであり，これはたと え微細な紐状に分断されていても伝ぱ火炎の構造をとる限り ありえないと考えられるからである。実際,多くの研究の結 果は, 観察した火炎が分散反応領域である根拠として, 温度 分布に中間温度領域か現れることを挙げており，各種火炎発 光の空間的分布のずれは Summerfield らか指摘したものより はるかに微小である。しかし Fig.4 に示した構造であれば Summerfield らの観察した distributed reaction zone を説明でき る。Summerfield らが用いたのはパイロットバーナ付きの二 次元スロットバーナであり，Fig.4に示した火炎構造におい て伝ぱ火炎面の局所消炎面積比率がかな高くても，乥の背 後て既燃ガスに希釈された予混合気が分散反応的な反応を進 行させることができたと考えられる。光して高速の流れ場中 で伝ぱ火炎よりも緩慢な速度で反応が起こったため,空間的 に反応段階が分離して観察されたと考えられる。なお，高橋 らの研究 ${ }^{22), 23)}$ て観察された，希薄可燃限界以下の予混合気 か高温パイロット流との混合層中で反応する分散反応領域火 炎においては, $\mathrm{OH}, \mathrm{CH}$ ラジカル自発光ポイント測定信号 間の相互相関係数の低下が確認されており,化学反応の各種 段階にある領域が空間的に分散している構造であったと考え られる。このことから，高橋らの観察した火炎は Summerfield らの観察した火炎に近い性質を持っていたといえる。

\section{4 . 分散反応領域火炎の出現条件}

つぎに , 2 章に示した二つの火炎構造の出現条件について 考える。まず，Fig.3 および Fig.4に示した構造は，しわ状層 流火炎が局所消炎を起こすことが必要条件であることは明ら かである。これについては Kalrovitz ${ }^{32}$ らの伸長消炎の理論を 一般化した Klimov と Williams の基準 ${ }^{33)}$ が知られている。

$$
l_{k}<\delta_{F}
$$

ここで， $l_{K}$ は乱流のコルモゴロフスケール,$\delta_{F}$ は層流

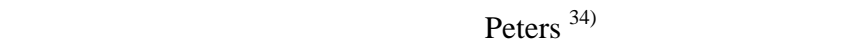
ロビッツ数による評価と等価であることが示され，分散反応 領域火炎の出現条件の一つととらえられてきたが,なぜ局所 消炎現象が分散反応領域火炎の出現条件となるのかは従来の 火炎モデルからは決して明らかではなかった ${ }^{35) 。 し か し ~} 2$ 章に示した火炎モデルでは局所消炎を起こす条件が分散反応 領域の出現条件と一致することは無理なく説明できる。

つぎに ,Fig.3 の構造と Fig.4 の構造の境界条件について考 えてみる。これらの構造の違いは, 局所消炎後, 伝ぱ火炎が 再形成されるか否かの違いである。Fig.4 の構造において， 伝ぱ火炎が再形成されないのは,局所消炎部分から既燃ガス 中に通り拔けた乱流渦が，伝ぱ火炎再形成にかかる着火遅れ 時間内に既燃ガスとの混合により希釈されてしまうからであ つた。つまり，局所消炎部分から既燃ガス層に通り抜けた乱 流渦のスケール $l_{e}$ と, 兴の強さ $u_{l e}$ 'の比の值が兴の着火遅 れ時間 $t_{r i}$ より小さければ，渦全体が再着火までに既燃ガス によって希䣋されるといえる。

$$
\frac{l_{e} / u_{l e}{ }^{\prime}}{t_{r i}}<1
$$

ここで着火遅れ時間が混合気の化学反応特性時間 $\tau_{c}$ とほ ぼ等しく，局所消炎が乱流のマクロスケール $L_{E}$ で起こり， 乱流のパワーが兴のマクロスケール付近から弚れ以下に集中 しているとすると

$$
\begin{aligned}
& t_{r i} \approx \tau_{c} \\
& l_{e} \approx L_{E} \\
& u_{l e}{ }^{\prime} \approx u^{\prime}
\end{aligned}
$$

とおける。ここで, $u^{\prime}$ は乱流の乱れ強さである。よって， 式(2)は

$$
\frac{L_{E} / u^{\prime}}{\tau_{c}}=\frac{\tau_{t}}{\tau_{c}}=D a<1
$$

と表され，公ムケラ数 $D a$ により判定できることになる。 ここで， $\tau_{t}$ は乱流混合特性時間である。つまり Fig.3 の構 造は，Da>1の条件て現れ，Fig.4の構造は， $D a<1$ の条件で見られることになる。この条件は Borghi の火炎位 相図 ${ }^{36)}$ において, 乥れ艺れ distributed reaction zone, well-stirred reactor として分類されている条件と一致している。これまで これらの火炎構造の違いについては明確な説明はなされてお らず,明らかではなかった。ここで提示したモデルに基づけ ば，Fig.3 に示した構造が Borghi の分類による distributed reaction zone であり，従来のほとんどの研究で観察されてい たのはこの構造の火炎であったと考えられる。光して ,Fig.4 に示した構造が Borghi の分類による well-stirred reactor であ り, Summerfield らや高橋らにより観察された distributed reaction zone はこの構造の火炎であったと考えられる。

5 . 結 言

非常に希薄な予混合気流を用いて，比較的大スケール・弱 
乱流強度の流れ場に高強度乱流場と同樣のダムケラ数の小さ い乱流予混合火炎を形成し火炎構造観察を行った結果から得 られた火炎のマクロ構造に基づいて, 高強度乱流場における 予混合火炎の微細構造について考察し，以下の結論を得た。 (1) 高強度乱流場に形成される予混合火炎の構造について 2 つのモデルを提案した。

(2) 従来の研究結果との対比の結果, これまで分散反応領域 火炎を観察したとされてきた各種研究の中で, Summerfiled らや高橋らによって観察された火炎と，关の他の研究者によ って観察されてきた火炎とは異なる構造であり，光れ艺れ今 回提案した $2 つ$ つ炎構造に該当すると考えられる。

(3) 今回提案した 2つの火炎モデルの出現条件について検討 した結果，これらは Borghi ダイアグラムの分類による distributed reaction zone と well-stirred reactor に該当すると考 えられる。

\section{参 考 文 献}

1) M. Summerfield, S.H. Reiter, V. Kebely and R.W. Mascolo : Jet Propulsion, 24 (1954) 254.

2) M. Summerfield, S.H. Reiter, V. Kebely and R.W. Mascolo : Jet Propulsion, 25 (1955) 377.

3) J. Chomiak : Proceedings of the Combustion Institute, 16 (1976) 1665.

4) H. Tennekes : The Physics of Fluids, 11 (1968) 669.

5) R.J. Tabaczynski, F.H. Trinker and B.A.S. Shannon : Combust. Flame, 39 (1980) 111.

6) 小林秀昭，北野三千雄 : 燃焼の科学と技術, 2 (1994) 27.

7) A. Yoshida : Proceedings of the Combustion Institute, 22 (1988) 1471.

8) 吉田 亮, 成澤道則, 辻 廣 : 日本機械学会論文集, 58-552B (1992) 2571.

9) A. Yoshida, M. Narisawa and H. Tsuji : Proceedings of the Combustion Institute, 24, 519.

10) 吉田 亮, 成澤道則, 辻 廣, 廣瀬龍興: 日本機械学会論文集, 59-560B (1993) 1401.

11) 高橋丈雄 : 大阪大学博士論文 第 3 章 (1991)

12) Y.C. Chen, N. Peters, G.A. Schneemann, N. Wruck, U. Renz and M.S. Mansour : Combust. Flame, 107 (1996) 223.
13) G. Damköhler : Z. Elektrochem., 46 (1940) 601; NACA TM 1112 (1947) [English Trans.].

14) D.R. Ballal and A.H. Lefebvre : Proc. Roy. Soc. Lond., A344-1637 (1975) 217.

15) 古川純一, 原田栄一, 平野敏右 : 日本機械学会論文集, 55-520B (1989) 3758.

16) J. Furukawa, E. Harada and T. Hirano : Proceedings of the Combustion Institute, 23 (1990), 789.

17) 丸田薰, 古川純一, 五味 努, 平野敏右: 日本機械学会論文 集, 59-566B (1993) 3277.

18) A. Buschmann, F. Dinkelacker, T. Schäfer, M. Schäfer and J. Wolfrum : Proceedings of the Combustion Institute, 26 (1996) 437.

19) D.A. Knaus and F.C. Gouldin : Proceedings of the Combustion Institute, 28 (2000) 367.

20) H. Kido, M. Nakahara, K. Nakashima and J. Hashimoto : Proceedings of the Combustion Institute, 29 (2002) 1855.

21) F.A. Williams : Combust. Flame, 26 (1976) 269.

22) 高橋丈雄, 香月正司, 水谷幸夫 : 日本機械学会論文集, 55-511B (1989)859.

23）高橋丈雄，香月正司，水谷幸夫 : 日本機械学会論文集, 58-547B (1992) 929.

24) M.S. Mansour, N. Peters and Y.C. Chen : Proceedings of the Combustion Institute, 27 (1998) 767.

25) F. Dinkelacker, A. Soika, D. Most, D. Hofmann, A. Leipertz, W. Plifke and K. Döbbeling : Proceedings of the Combustion Institute, 27 (1998) 857.

26) 㴊端 学, 香月正司 : 高温学会誌, 24-4 (1998) 137.

27) 㴊端学, 香月正司, 水谷幸夫 : 日本機械学会論文集, 66-652B (2000) 3249.

28) M. Murayama and T. Takeno : Proceedings of the Combustion Institute, 22 (1988) 551.

29) F.C. Gouldin : Combust. Flame, 68 (1989) 249.

30) 吉田 亮, 安藤美彦, 柳澤 忠, 辻 廣 : 燃焼の科学と技術, 1 (1992) 37.

31) 吉田 亮, 柳澤 忠, 笠原正広, 过 廣 : 燃焼の科学と技術, 2 (1994) 39.

32) B. Karlovitz, D.W. Denniston, D.H. Knapschaefer and F.E. Wells : Proceedings of the Combustion Institute, 4 (1953) 613.

33) F.A. Williams : Combust. Flame, 26 (1976) 269.

34) N. Peters : Proceedings of the Combustion Institute, 21 (1986) 1231.

35) R.G. Abdel-Gayed and D. Bradley : Combust. Flame, 76 (1989) 213.

36) N. Peters : in Turbulent reactive flows, R. Borghi and S.N.B. Eds. Murthy, Springer-Verlag., 242. 